\title{
Comparison of and correlation between the characteristics of agricultural topsoil and subsoil at the southern coast of Finland
}

\author{
RAILI JOKINEN \\ University of Helsinki, Department of Agricultural Chemistry, \\ SF-00710 HELSINKI, Finland
}

\begin{abstract}
Topsoil and subsoil samples were taken at 382 sites from the agricultural area of Viikki Experimental Farm, University of Helsinki. The samples were determinated for particle size distribution, $\mathrm{pH}\left(\mathrm{CaCl}_{2}\right)$, organic $\mathrm{C} \%$, at $\mathrm{pH} 7$ exchangeable $\mathrm{Ca}, \mathrm{Mg}$ and $\mathrm{K}$, effective cation exchange capacity $(\mathrm{ECEC})$, exchange acidity $(\mathrm{Al}+\mathrm{H})$ and plant available (Bray 1) P. The differences between topsoil and subsoil were studied taking into consideration the fertilization and liming during the past ten years before sampling. The correlations between soil characteristics were also studied.

The clay $(<2 \mu \mathrm{m})$ and silt $(2-20 \mu \mathrm{m})$ contents, exchangeable $\mathrm{Mg}$ and exchange acidity were lower in the topsoil than in the subsoil; as for the remaining characteristics, the values for topsoil were higher than those for subsoil. The subsoil seemed to be more heterogenic than the topsoil.

There was a closer correlation between exchangeable $\mathrm{Ca}, \mathrm{Mg}$ and $\mathrm{K}$ and the clay content in the subsoil than in the topsoil. In Litorina soils, there was a weak correlation between exchangeable cations and clay. It is more difficult to predict the cation contents on the basis of soil particle size distribution in soils cropped intensively, since fertilization and liming have changed the original contents.

Vertical movement of applied Ca occurred slightly, possibly because the topsoils were rich in organic $\mathrm{C}$. There was some correlation between organic $\mathrm{C}$ and exchangeable $\mathrm{Mg}$ or $\mathrm{K}$, indicating a minor effect of organic matter on the leaching of these cations. The plant available P content of the subsoil was about $10 \%$ of that of the topsoil irrespective of the amount of $\mathrm{P}$ applied.

Clay and organic $\mathrm{C}$ contents were the main constituents of effective cation exchange capacity in the topsoil; in the subsoil the significance of clay was greatest.
\end{abstract}

\section{Introduction}

LAKANEN and HYVÄrINEN (1971) and URVAS et al. (1978) observed close correlations in the subsoil between particle size distribution and some properties indicating soil fertility.
An increase in the clay content seemed to increase the $\mathrm{pH}\left(\mathrm{H}_{2} \mathrm{O}\right)$ and acid ammonium acetate extractable $\mathrm{Ca}$ and $\mathrm{K}$, and to decrease the $\mathrm{P}$ content. According to the above studies, the requirement for supply of $\mathrm{Ca}, \mathrm{K}$

Index words: topsoil, subsoil, clay, silt, organic $\mathrm{C}$, exchangeable $\mathrm{Ca}, \mathrm{Mg}, \mathrm{K}$, exchange acidity, effective $\mathrm{CEC}$, Bray $1 \mathrm{P}$, fertilization, liming 
and $\mathrm{P}$ should be determined on the basis of the particle size distribution, at least in some degree. The subsoil is, however, only seldom analysed for soil fertility.

The majority of plants cultivated in Finland have a relatively shallow root system (SAlonen 1949, KÄHÄri and Elonen 1969). Also the acidity of subsoil may restrict the growth of roots: The nutrients of the topsoil are therefore taken up by plants more intensively than those of the subsoil. In case of shortage of nutrients in the topsoil the resources of subsoil may be of importance to the plants.

On farms where the agricultural soils have been fertilized intensively over a long period, some nutrients applied may have a tendency to be enriched in the subsoil. The effects of fertilization on the nutrient content of the subsoil are difficult to study, because they require special arrangements. The results of leaching experiments carried out in fields and in laboratory indicate the movement of basic cations (WIKLANDER 1970, HARTIKAINEN 1978 a) to be greater than that of phosphorus (HARTIKAINEN 1978 b).

The aim of this study was to elucidate the differences between topsoil and subsoil in some characteristics indicating agricultural productivity of soil. The results were compared with the fertilization and liming done during the past ten years before sampling. The correlations between soil properties were studied both for topsoil and subsoil.

\section{Materials and methods}

The soil samples of this study were collected from the agricultural area of Viikki Experimental Farm, University of Helsinki. The method of systematic sampling has been reported previously by JOKINEN (1983). The present material consisted of topsoil $(0-25$ $\mathrm{cm})$ and subsoil $(30-50 \mathrm{~cm})$ samples from 382 sampling sites.

The methods of soil analyses for determination of particle size distribution,
$\mathrm{pH}\left(\mathrm{CaCl}_{2}\right)$, organic $\mathrm{C} \%$, at $\mathrm{pH} 7$ exchangeable $\mathrm{Ca}, \mathrm{Mg}$ and $\mathrm{K}$, effective cation exchange capacity $(\mathrm{ECEC})$, exchange acidity $(\mathrm{Al}+\mathrm{H})$ and plant available (Bray 1) P were the same as those applied in the first part of this study (JOKINEN 1983).

The data on fertilization and liming are listed on the basis of records made at Viikki Experimental Farm (Table 1). The area of field 54 is about 17 hectares. Two or three agricultural plants were grown in this field every year, and different types and amounts

Table 1. Amounts of $\mathrm{P}, \mathrm{K}$ and $\mathrm{Mg}(\mathrm{kg} / \mathrm{ha})$ applied in fertilizers, manures and limestone during the past ten years before soil sampling.

\begin{tabular}{crrrrrr}
\hline \multirow{2}{*}{$\begin{array}{l}\text { Field } \\
\text { number }\end{array}$} & $\begin{array}{c}\text { Area } \\
\text { hectares }\end{array}$ & $\begin{array}{c}\text { Sampling } \\
\text { year }\end{array}$ & & $\mathrm{P}$ & $\mathrm{K}$ & $\mathrm{Mg}$ \\
\cline { 5 - 7 } & & & & \multicolumn{3}{c}{$\mathrm{kg} / \mathrm{ha}$} \\
\hline 49 & 7.27 & 1979 & & 285 & 735 & 60 \\
54 & 17.18 & 1979 & 740 & 1540 & 840 \\
86 & 7.37 & 1980 & 610 & 1040 & 110 \\
88 & 5.22 & 1980 & 610 & 1040 & 110 \\
89 & 5.28 & 1980 & 320 & 510 & 650 \\
96 & 10.29 & 1980 & 340 & 605 & 155 \\
97 & 3.60 & 1980 & 400 & 765 & 30 \\
98 & 5.82 & 1980 & 370 & 985 & 30 \\
\hline
\end{tabular}

Table 2. Classification of topsoil and subsoil materials according to clay $(<2 \mu \mathrm{m}) \%$, organic C $\%$ and $\mathrm{pH}\left(\mathrm{CaCl}_{2}\right)$ (in both materials $\mathrm{n}=382$ ).

\begin{tabular}{crr}
\hline & \multicolumn{2}{c}{ Number of soil samples } \\
\cline { 2 - 3 } & Topsoils & Subsoils \\
\hline Clay $(<2 \mu \mathrm{m}), \%$ & & \\
$<30$ & 181 & 105 \\
$30-60$ & 197 & 197 \\
$>60$ & 4 & 80 \\
Organic C, \% & & \\
$\leqq 1.6$ & & 207 \\
$1.7-3.4$ & 108 & 129 \\
$3.5-6.9$ & 179 & 45 \\
$7.0-11.5$ & 91 & 1 \\
$11.6-23.2$ & 4 & \\
pH(CaCl) & & 154 \\
$\leqq 4.4$ & 14 & 93 \\
$4.5-5.4$ & 209 & 135 \\
$5.5-6.4$ & 144 & \\
₹6.5 & 15 & \\
\hline
\end{tabular}


of fertilization were applied to each plant. The total amounts of nutrients applied per hectare during the past ten years are the sums of weighed means calculated yearly. The nutrient contents of cattle manure and liquid pig manure have not been analyzed, and the total amounts of $\mathrm{P}, \mathrm{K}$ and $\mathrm{Mg}$ applied therein are estimated according to the mean contents presented by KERÄNEN (1966) and KÄHÄRI (1974). In 1975 (field 54) and 1979 (field 89), liming was performed with dolomitic limestone $(7-10 \% \mathrm{Mg}$ ) and in 1971 (field 89 and 97) with calcitic limestone.

Mean $(\overline{\mathrm{x}})$, standard deviation (sd) and coefficient of variation (cv) were estimated for the topsoil and subsoil samples separately. The significances of the differences between topsoil and subsoil were analyzed by t-test. The linear correlation between soil characteristics were also calculated for these two soil layers (STEel and TORrie 1960).

The subsoil material included 120 samples originating from the period of the Litorina Sea, and the respective topsoil was also classified in this group. Topsoil and subsoil analyses were applied both to Litorina and nonLitorina soils.

\section{Results}

Characteristics of soil layers

The topsoil and subsoil materials were classified into three groups according to clay ( $<2 \mu \mathrm{m}$ ) content, into five groups according to organic $\mathrm{C} \%$ and into four groups according to $\mathrm{pH}\left(\mathrm{CaCl}_{2}\right)$ (Table 2). Clay soils (30-60\% clay) accounted equally commonly in the topsoil and subsoil materials. Heavy clays ( $>60 \%$ clay) existed mainly in the subsoil and the number of non-clay samples ( $<30 \%$ clay) was higher in the topsoil than in the subsoil. The subsoil material included more samples in the groups of lower organic C $\%$ and $\mathrm{pH}\left(\mathrm{CaCl}_{2}\right)$ than did the topsoil material. The number of organic soils (org. C 11.6-23.2 \%) was low, thereby both materials consisted mainly of mineral soils.

Comparison of the two soil layers showed that most parameters measured were higher in the topsoil than in the subsoil (Table 3). The exchangeable $\mathrm{Mg}$ and exchange acidity formed an exception with higher values in the subsoil. The difference between topsoil and subsoil was significant for each of the parameters studied.

Table 3. Soil properties of topsoils and subsoils (mean, standard deviation, range, coefficient of variation).

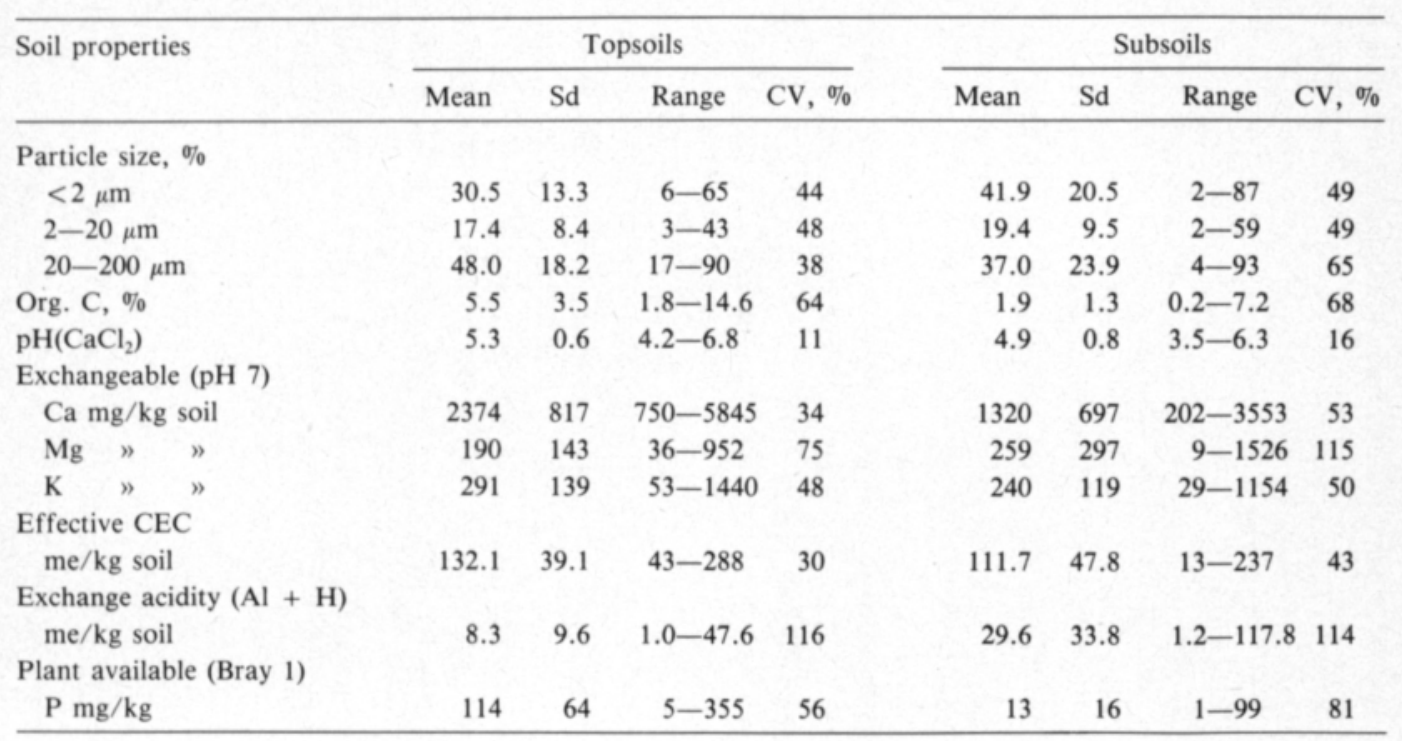




\begin{tabular}{|c|c|c|}
\hline 。 & 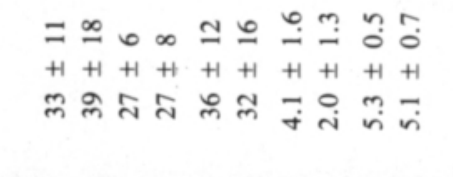 & 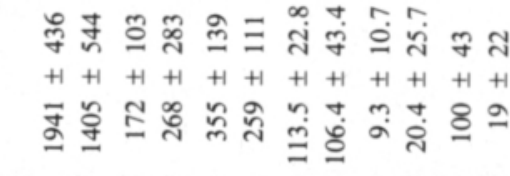 \\
\hline 5 & 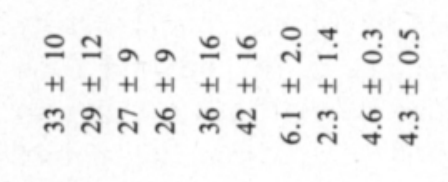 & 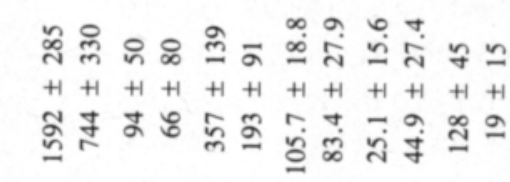 \\
\hline$\%$ & 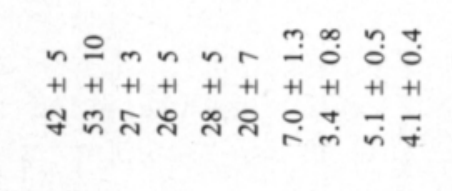 & 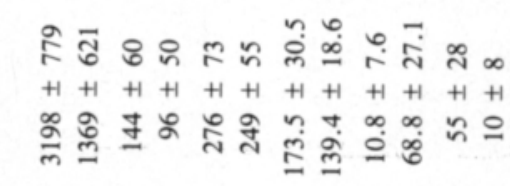 \\
\hline 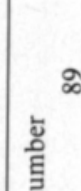 & 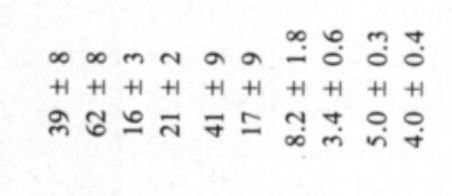 & 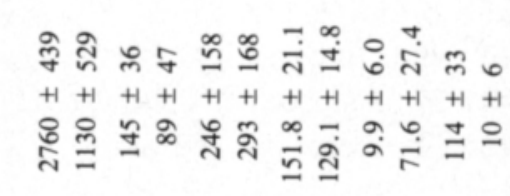 \\
\hline$\left.\right|_{\infty} ^{\frac{\pi}{v e}}$ & 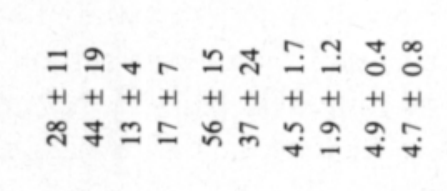 & 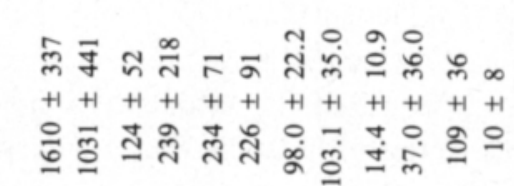 \\
\hline . & 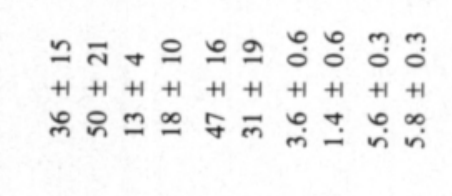 & 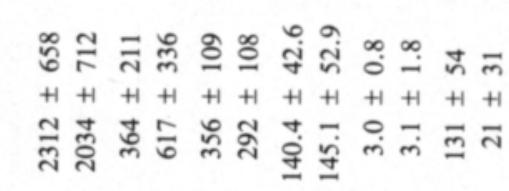 \\
\hline 苟 & 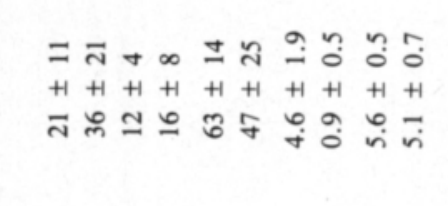 & 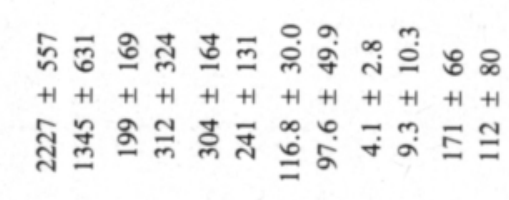 \\
\hline$g$ & 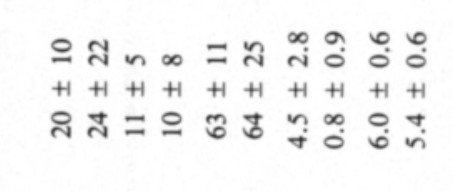 & 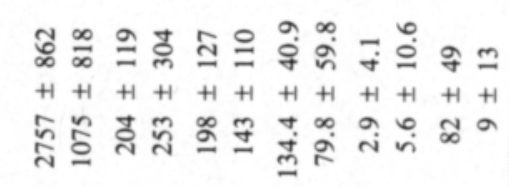 \\
\hline & 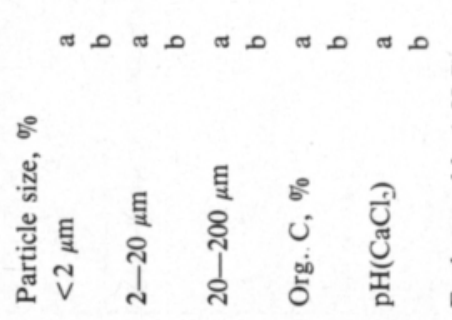 & 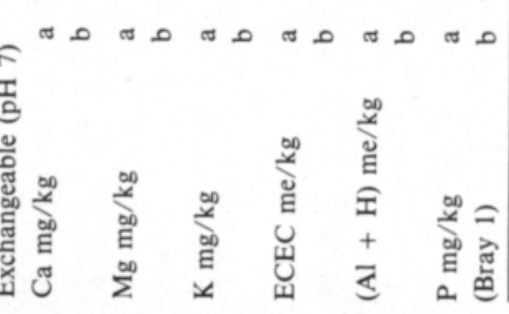 \\
\hline
\end{tabular}


The coefficients of variation were higher in the subsoil material than in the topsoil. Thus, the subsoil seemed to be somewhat more heterogenic. Also the ranges were the widest in the subsoil, with the exceptions of organic $\mathrm{C} \%$, exchangeable $\mathrm{Ca}$ and $\mathrm{K}$.

Considerably higher contents of exchangeable Ca were observed in the topsoil than in the subsoil in fields limed, but also in fields not limed during the past ten years before sampling (Table 4). The values of $\mathrm{pH}\left(\mathrm{CaCl}_{2}\right)$ and exchange acidity were in accordance with the exchangeable $\mathrm{Ca}$ contents. The vertical movement of $\mathrm{Ca}$ seemed to be insignificant in these soils.

Despite liming with dolomitic limestone the mean content of exchangeable $\mathrm{Mg}$ was lower in the topsoil than in the subsoil (Table 3). The highest total amount of $\mathrm{Mg}$ applied in limestone and manures during the past ten years was $840 \mathrm{~kg} / \mathrm{ha}$ (field 54) and the lowest amount $30 \mathrm{~kg} / \mathrm{ha}$ (field 98). The exchangeable $\mathrm{Mg}$ contents of topsoil and subsoil in these fields were $199 \pm 169 \mathrm{mg} / \mathrm{kg}$ and $312 \pm 324 \mathrm{mg} / \mathrm{kg}(54), 172 \pm 103 \mathrm{mg} / \mathrm{kg}$ and $268 \pm 283 \mathrm{mg} / \mathrm{kg}$ (98) on average, respectively (Table 4). In Litorina soils, the exchangeable $\mathrm{Mg}$ content of the topsoil was somewhat higher than that of the subsoil (fields $89,96,97)$. In fields 89 and 96, the exchangeable $\mathrm{Mg}$ contents of the topsoil were nearly the same, and also close to those of the subsoil. However, the amounts of applied $\mathrm{Mg}$ were $650 \mathrm{~kg} / \mathrm{ha}$ and $155 \mathrm{~kg} / \mathrm{ha}$ in respective fields.

The mean content of exchangeable $\mathrm{K}$ of the topsoil was higher than that of the subsoil in the whole material, as well as in individual fields, despite the increased clay content in the subsoil. Applied K may affect more the exchangeable $\mathrm{K}$ of the topsoil than that of the subsoil when annual crops are grown. In

Table 5. Characteristics of topsoil and subsoil in Litorina and non-Litorina soils (mean, standard deviation, range).

\begin{tabular}{|c|c|c|c|c|c|c|}
\hline & \multicolumn{3}{|c|}{ Topsoil } & \multicolumn{3}{|c|}{ Subsoil } \\
\hline & Mean & Sd & Range & Mean & Sd & Range \\
\hline & \multicolumn{6}{|c|}{ Litorina soils $(\mathrm{n}=120)$} \\
\hline Particles $<2 \mu \mathrm{m}, \%$ & 39.4 & 7.5 & $13.5-49.9$ & 50.5 & 14.5 & $7.3-75.0$ \\
\hline Org. C, $\%$ & 7.2 & 1.8 & $2.5-11.7$ & 3.2 & 1.0 & $0.5-7.2$ \\
\hline $\mathrm{pH}\left(\mathrm{CaCl}_{2}\right)$ & 5.0 & 0.4 & $4.2-6.5$ & 4.1 & 0.4 & $3.6-5.8$ \\
\hline \multicolumn{7}{|l|}{ Exchangeable (pH 7) } \\
\hline $\mathrm{Ca} \mathrm{mg} / \mathrm{kg}$ & 2777 & 874 & $1136-4780$ & 1188 & 599 & $293-3414$ \\
\hline $\mathrm{Mg} \mathrm{mg} / \mathrm{kg}$ & 134 & 56 & $45-357$ & 89 & 57 & $21-394$ \\
\hline $\mathrm{K} \mathrm{mg} / \mathrm{kg}$ & 284 & 119 & $114-970$ & 249 & 107 & $69-1154$ \\
\hline \multicolumn{7}{|l|}{ Effective CEC } \\
\hline $\mathrm{me} / \mathrm{kg}$ & 154.9 & 36.7 & $69.5-250.4$ & 126.0 & 29.0 & $19.8-184.2$ \\
\hline \multicolumn{7}{|l|}{ Exchange acidity } \\
\hline $\mathrm{me} / \mathrm{kg}$ & 13.3 & 11.0 & $2.3-47.6$ & 65.0 & 28.8 & $3.3-117.8$ \\
\hline \multicolumn{7}{|c|}{ Non-Litorina soils $(n=262)$} \\
\hline Particles $<2 \mu \mathrm{m}, \%$ & 26.5 & 13.4 & $5.6-65.1$ & 38.1 & 21.7 & $1.9-87.2$ \\
\hline Org. C, \% & 4.4 & 2.0 & $1.8-14.6$ & 1.3 & 1.0 & $0.2-5.6$ \\
\hline $\mathrm{pH}\left(\mathrm{CaCl}_{2}\right)$ & 5.5 & 0.6 & $4.2-6.8$ & 5.2 & 0.7 & $3.5-6.3$ \\
\hline \multicolumn{7}{|l|}{ Exchangeable ( $\mathrm{pH} 7)$} \\
\hline $\mathrm{Ca} \mathrm{mg} / \mathrm{kg}$ & 2222 & 692 & $1610-5845$ & 1379 & 731 & $202-3553$ \\
\hline $\mathrm{Mg} \mathrm{mg} / \mathrm{kg}$ & 215 & 162 & $36-952$ & 336 & 33 & $9-1333$ \\
\hline $\mathrm{K} \mathrm{mg} / \mathrm{kg}$ & 294 & 147 & $53-1440$ & 234 & 121 & $29-795$ \\
\hline \multicolumn{7}{|l|}{ Effective CEC } \\
\hline $\mathrm{me} / \mathrm{kg}$ & 122.0 & 35.9 & $43.4-287.5$ & 105.2 & 53.0 & $13.4-237.1$ \\
\hline \multicolumn{7}{|l|}{ Exchange acidity } \\
\hline $\mathrm{me} / \mathrm{kg}$ & 6.1 & 8.1 & $1.0-39.7$ & 13.8 & 21.8 & $1.2-98.2$ \\
\hline
\end{tabular}


the topsoil of field 89 , the organic $\mathrm{C} \%$ was high, in the subsoil, the clay content was high. Perennial ley was grown in this field, and the uptake of $\mathrm{K}$ possibly exceeded the $\mathrm{K}$ supply, resulting in the low exchangeable $\mathrm{K}$ content of topsoil.

The plant available (Bray 1) P of the subsoil was about $10 \%$ of that of the topsoil. Sugar beet was grown in field 54, and it was fertilized with high amounts of $\mathrm{P}$. The difference between the $\mathrm{P}$ content in the topsoil $(171 \pm 66 \mathrm{mg} / \mathrm{kg})$ and subsoil (112 \pm 80 $\mathrm{mg} / \mathrm{kg}$ ) was smaller in this field than in any other field. In fields 86 and 88 , on the other hand, the amounts of plant available $\mathrm{P}$ of the soil layers deviated from the above, as was the case in other fields in spite of the high amount of $\mathrm{P}$ applied.

In general, the ECEC was significantly higher in the topsoil than in the subsoil. The fields 86 and 88 were exceptional with almost equal ECEC's in both soil layers.

The 120 Litorina soil samples deviated from the rest. The high content of exchange acidity and low content of exchangeable $\mathrm{Mg}$ in the subsoil were characteristic features of the Litorina soils (Table 5). Both layers exhibited higher clay and organic $\mathrm{C}$ contents than those of non-Litorina soils; consequently the ECEC, too, was higher. The proportion of $(\mathrm{Al}+\mathrm{H})$ in the ECEC was low in the non-Litorina soils (topsoil $5 \%$, subsoil $13 \%$ ) and in the top layer of Litorina soils $(9 \%)$. In the Litorina subsoil the respective value was very high $(52 \%)$.

\section{Correlation between soil characteristics}

The ECEC was less dependent on the clay content in the topsoil than in the subsoil (Table 6). Its dependence on organic C \% seemed to be nearly the same in both layers. These two soil properties exerted the highest positive effects on the ECEC. Because of the low content of organic $C$ in the subsoil, the significance of clay for the ECEC was great. With increasing amount of fine sand $(20-60$ $\mu \mathrm{m})$ the ECEC decreased, whereas the silt fraction $(2-20 \mu \mathrm{m})$ had a positive, but minor effect on the ECEC.

The dependence between clay content and the exchangeable cations $\mathrm{Ca}$ and $\mathrm{K}$ seemed to be somewhat weaker in the topsoil than in the subsoil. Exchangeable $\mathrm{Mg}$ showed an equal correlation with clay in both soil layers. There was a positive correlation between the silt content and exchangeable $\mathrm{Ca}$ or $\mathrm{K}$ and a negative correlation between silt content and exchangeable $\mathrm{Mg}$. All in all, the correlations were poor. The same applied to the effects of fine sand fraction on the exchangeable cations. The increasing content of fine silt $(2-6 \mu \mathrm{m})$ increased the exchangeable $\mathrm{K}$ slightly (topsoil $\mathrm{r}=0.22^{* *}$, subsoil $\mathrm{r}=$

Table 6. Correlation coefficients $(\mathrm{r})$ between some properties in topsoil and subsoil.

\begin{tabular}{lccc}
\hline & Clay, $\%$ & Silt, $\%$ & Organic C, $\%$ \\
\hline Exchangeable $(\mathrm{pH} 7)$ & & Topsoils & \\
$\mathrm{Ca} \mathrm{mg} / \mathrm{kg}$ & $0.30^{* *}$ & $0.11^{*}$ & $0.38^{* *}$ \\
$\mathrm{Mg} \mathrm{mg} / \mathrm{kg}$ & $0.46^{* *}$ & $-0.12^{*}$ & $-0.26^{* *}$ \\
$\mathrm{~K} \mathrm{mg} / \mathrm{kg}$ & $0.42^{* *}$ & $0.18^{* *}$ & -0.02 \\
$\mathrm{Effective} \mathrm{CEC}, \mathrm{me} / \mathrm{kg}$ & $0.41^{* *}$ & $0.27^{* *}$ & $0.48^{* *}$ \\
$\mathrm{pH}\left(\mathrm{CaCl}_{2}\right)$ & $-0.25^{* *}$ & & $-0.57^{* *}$ \\
$\mathrm{Exchangeable}(\mathrm{pH} 7)$ & & Subsoils & \\
$\mathrm{Ca} \mathrm{mg} / \mathrm{kg}$ & $0.60^{* *}$ & 0.05 & 0.05 \\
$\mathrm{Mg} \mathrm{mg} / \mathrm{kg}$ & $0.48^{* *}$ & $-0.16^{*}$ & $-0.30^{* *}$ \\
$\mathrm{~K} \mathrm{mg} / \mathrm{kg}$ & $0.72^{* *}$ & $0.13^{*}$ & $0.30^{* *}$ \\
$\mathrm{Effective} \mathrm{CEC}, \mathrm{me} / \mathrm{kg}$ & $0.86^{* *}$ & $0.18^{* *}$ & $0.37^{* *}$ \\
$\mathrm{pH}\left(\mathrm{CaCl}{ }_{2}\right)$ & $-0.14^{*}$ & & $-0.63^{* *}$ \\
\hline
\end{tabular}


$\left.0.40^{* *}\right)$, but gave no more evidence of the exchangeable $\mathrm{Ca}$ or $\mathrm{Mg}$ contents than did total silt fraction.

When the material was classified into nonclay ( $<30 \%$ clay) and clay ( $\leqq 30 \%$ clay) soils, the dependence of exchangeable $\mathrm{Ca}$, $\mathrm{Mg}$ or $\mathrm{K}$ (y) on the clay content (x) was as follows $(r=$ correlation coefficient, $b=$ regression coefficient): of exchangeable $\mathrm{Ca}, \mathrm{Mg}$ or $\mathrm{K}$ in the soils deposited during the Litorina Sea period.

There was a closer correlation between organic $\mathrm{C}$ and exchangeable $\mathrm{Ca}$ in the whole material of topsoils than in subsoils. The leaching of soil exchangeable $\mathrm{Ca}$ or applied $\mathrm{Ca}$ may be lower in soils rich in organic matter. In Litorina soils this trend was apparent. The amount of organic $\mathrm{C}$ and exchangeable

\begin{tabular}{|c|c|c|c|c|c|c|c|c|}
\hline \multirow{3}{*}{$\begin{array}{l}\text { Exch. } \\
\text { cation }\end{array}$} & \multicolumn{4}{|c|}{ Non-clay soils } & \multicolumn{4}{|c|}{ Clay soils } \\
\hline & \multicolumn{2}{|c|}{$\begin{array}{c}\text { Topsoil } \\
(\mathrm{n}=181)\end{array}$} & \multicolumn{2}{|c|}{$\begin{array}{l}\text { Subsoil } \\
(\mathrm{n}=105)\end{array}$} & \multicolumn{2}{|c|}{$\begin{array}{c}\text { Topsoil } \\
(\mathrm{n}=201)\end{array}$} & \multicolumn{2}{|c|}{$\begin{array}{c}\text { Subsoil } \\
(n=277)\end{array}$} \\
\hline & $\mathrm{r}$ & b & $\mathrm{r}$ & b & $\mathrm{r}$ & b & $\mathbf{r}$ & b \\
\hline $\mathrm{Ca} \mathrm{mg} / \mathrm{kg}$ & 0.19 & 2.11 & $0.71^{* *}$ & 3.83 & $0.29 * *$ & 3.19 & $0.21 * *$ & 1.06 \\
\hline $\mathrm{Mg} \mathrm{mg} / \mathrm{kg}$ & $0.58 * *$ & 0.59 & $0.63^{* *}$ & 0.69 & $0.43^{* *}$ & 1.14 & $0.37^{* *}$ & 0.97 \\
\hline $\mathrm{K} \mathrm{mg} / \mathrm{kg}$ & $0.39 * *$ & 0.73 & $0.69^{* *}$ & 0.50 & 0.10 & 0.22 & $0.40^{* *}$ & 0.32 \\
\hline
\end{tabular}

In non-clay soils, the significance of clay content for exchangeable $\mathrm{Ca}, \mathrm{Mg}$ or $\mathrm{K}$ contents seemed to be greater in the subsoil than in the topsoil. In clay soils, the dependences on clay content were lower than in non-clay soils. The poor correlation between clay content and exchangeable $\mathrm{Mg}$ in the lower layer of clay soils may be due to the Litorina soils being included in this group. According to the regression coefficients, the increase in the clay content of the topsoil caused in the exchangeable $\mathrm{K}$ of non-clay soils about a 3 -fold increase to that of clay soils.

In Litorina soils, the correlations between clay content ( $\mathrm{x}$ ) and exchangeable cations (y) were lower than in non-Litorina soils as indicated by the following coefficients of linear correlation (r) and regression (b):
Mg or K correlated poorly in both soil layers, indicating a minor effect of organic matter on the leaching of these cations.

The $\mathrm{pH}\left(\mathrm{CaCl}_{2}\right)$ of topsoil and subsoil seemed to decrease slightly with increasing clay content and more distinctly with increasing organic $\mathrm{C}$ content. The ECEC was almost independent of $\mathrm{pH}\left(\mathrm{CaCl}_{2}\right)$ (topsoil $r=0.15$, subsoil $r=0.06$ ), although the positive correlation between ECEC and clay or organic $\mathrm{C}$ did exist. Also the exchange acidity and ECEC were poorly correlated in the topsoil $(\mathrm{r}=-0.07)$ and subsoil $(\mathrm{r}=$ $\left.0.23^{* *}\right)$.

In the top layer of Litorina soils, the exchange sites were occupied mainly by $\mathrm{Ca}$ and $\mathrm{Mg}$ because of liming, and increasing amounts of $(\mathrm{Al}+\mathrm{H})$ caused a decrease in

\begin{tabular}{|c|c|c|c|c|c|c|c|c|}
\hline & \multicolumn{4}{|c|}{$\begin{array}{l}\text { Litorina soils } \\
\qquad(\mathrm{n}=120)\end{array}$} & \multicolumn{4}{|c|}{$\begin{array}{l}\text { Non-Litorina soils } \\
\quad(\mathrm{n}=262)\end{array}$} \\
\hline & \multicolumn{2}{|c|}{ Topsoil } & \multicolumn{2}{|c|}{ Subsoil } & \multicolumn{2}{|c|}{ Topsoil } & \multicolumn{2}{|c|}{ Subsoil } \\
\hline & $r$ & b & $\mathbf{r}$ & b & $\mathrm{r}$ & b & $\mathbf{r}$ & b \\
\hline $\mathrm{Ca} \mathrm{mg} / \mathrm{kg}$ & $0.37^{* * *}$ & 4.32 & $0.21^{*}$ & 0.85 & $0.32 * *$ & 1.67 & $0.76^{* *}$ & 2.17 \\
\hline $\mathrm{Mg} \mathrm{mg} / \mathrm{kg}$ & 0.09 & 0.07 & 0.13 & 0.05 & $0.73^{* *}$ & 0.89 & $0.72 * *$ & 1.09 \\
\hline $\mathrm{K} \mathrm{mg} / \mathrm{kg}$ & 0.15 & 0.23 & $0.42^{* *}$ & 0.31 & $0.56^{* * *}$ & 0.62 & $0.83^{* *}$ & 0.47 \\
\hline
\end{tabular}

The increasing clay content do not give clear evidence of the increasing amounts the ECEC $\left(\mathrm{r}=-0.43^{* *}\right)$. In the subsoil, the ECEC was greatly due to the acidity 
promoting cations, and the ECEC increased with increasing amount of $(\mathrm{Al}+\mathrm{H})(\mathrm{r}=$ $\left.0.44^{* *}\right)$.

\section{Discussion}

The samples of topsoil $(0-25 \mathrm{~cm})$ and subsoil $(30-50 \mathrm{~cm})$ were taken from the same sites and at the same time. Therefore the differences between the two soil layers are the same as they are in the nature. MARTtila (1965), Kaila $(1972,1973)$ and UrVaS et al. (1978) for example, collected topsoil and subsoil samples mostly from different sites, furthermore the soil samples of both materials differed in number. The results of above studies may show a trend to bias from natural conditions.

Both the topsoil and subsoil material consisted of 382 samples. The mean clay content was $31 \pm 13 \%$ in the topsoil and $42 \pm 21 \%$ in the subsoil and organic C content $5.5 \pm$ $3.5 \%$ and $1.9 \pm 1.3 \%$, respectively. The soils were acid with $\mathrm{pH}\left(\mathrm{CaCl}_{2}\right)$ values of $5.3 \pm 0.6$ and $4.9 \pm 0.8$, respectively. The exchangeable $\mathrm{Ca}$ and $\mathrm{K}$ contents, ECEC and plant available (Bray 1) P decreased, whereas exchangeable $\mathrm{Mg}$ and exchange acidity $(\mathrm{Al}+\mathrm{H})$ increased towards the subsoil. The same trend has been observed by MARTTILA (1965) and KaILA (1972) for the exchangeable cations and by KAILA (1971) for the ECEC in Finnish mineral soils.

In an earlier study (JOKINEN 1983), the number of soil samples needed for the accurate estimation of soil characteristics was calculated for the topsoil material on the basis of the coefficient of variation (w), Student's $\mathrm{t}$-value $(\mathrm{t})$ and allowable error $(\mathrm{p})$ according to the equation $n=t^{2} w^{2} / p^{2}$. If this equation were applied to subsoils, the number of samples needed would be greater than for topsoil because of the higher w-values in the subsoil. The subsoil seemed to be more heterogenic than the topsoil.

The ECEC of the topsoil was equally dependent on the clay and organic $\mathrm{C} \%$, in the subsoil clay was of great significance. KAILA
(1971) studied the ECEC of Finnish mineral soils and observed the dependence on clay to be in both soil layers very close and the dependence on organic $\mathrm{C}$ to be low. Her material consisted of both virgin and cultivated soils with a narrower range of organic $\mathrm{C} \%$ and a wider range of clay than in this material. Drake and Motro (1982) studied the dependences of potential CEC of New Jersey soils on clay and organic matter contents. In the horizon $\mathrm{A}$, the relative contributions of clay and organic matter were nearly equal, whereas in the horizons $\mathrm{B}$ and $\mathrm{C}$, the contribution of clay was great.

Increasing content of organic $\mathrm{C}$ in the topsoil seemed to protect the applied $\mathrm{Ca}$ against leaching. This effect was apparent in Litorina soils. The organic matter-metal complexes, including $\mathrm{Ca}$ complexes, are so strongly bound that they can be released at very acid pH only (Lewis and Brodbent 1961, StảlBERG 1984). Exchangeable $\mathrm{Mg}$ and $\mathrm{K}$ seemed not to have the same kind of protection by organic matter against leaching.

It is easier on the basis of clay content to predict the exchangeable $\mathrm{Ca}, \mathrm{Mg}$ or $\mathrm{K}$ content of the soil in non-Litorina soils than in Litorina soils. The positive dependence of cations on clay was weaker in clay soils than in non-clay soils. Fertilization and liming of soils cropped over a long period may change the original contents.

The effect of $P$ fertilization on the content of plant available (Bray 1) $\mathrm{P}$ in the subsoil was not observed. In one field only where high amounts of $\mathrm{P}$ were applied, some of it may have reached the subsoil because of the high content of organic $\mathrm{C}$ in the topsoil. According to SALONEN et al. (1973), the watersoluble $\mathrm{P}$ applied in fertilizers have a tendency to remain in this form in organic soils. The contamination of subsoil with topsoil was also possible because of some difficulties in subsoil sampling in 1979.

The availability for plants of exchangeable cations may be equal in the topsoil and subsoil. The availability is sooner dependent on the depth the roots reach. SAlonen (1952) 
stated that e.g. the $\mathrm{K}$ and $\mathrm{P}$ of subsoil were available for cereals in case $\mathrm{N}$ fertilization had been applied. In the Litorina soils included in this study, the nutrients of subsoil have a risk to remain out of use because of the acidity. Inversely in non-Litorina soils, the exchangeable $\mathrm{Mg}$ and $\mathrm{K}$ may be available for plants.

There was a weak negative correlation between clay percentage and $\mathrm{pH}\left(\mathrm{CaCl}_{2}\right)$. Assuming $\mathrm{pH}$ is the best indicator of the liming requirement of the soil, an increase in the clay content would raise the amount of lime needed for the elevation in $\mathrm{pH}$. In this respect similar (Ross et al. 1964) and opposite results (URVAs et al. 1978) have been achieved. The negative dependence of $\mathrm{pH}\left(\mathrm{CaCl}_{2}\right)$ on organic $\mathrm{C}$ content was closer than the negative dependence of $\mathrm{pH}$ on clay content. Therefore also the requirement of lime should increase with increasing organic $\mathrm{C} \%$.

\section{References}

DraKe, E.H. \& Motto, H.L. 1982. An analysis of the effects of clay and organic matter content on the cation exchange capacity of New Jersey soils. Soil Sci. 133: $281-288$.

Hartikainen, H. 1978 a. Leaching of plant nutrients from cultivated soils I. Leaching of cations. J. Scient. Agric. Soc. Finl. 50: 263-269.

- 1978 b. Leaching of plant nutrients from cultivated soils II. Leaching of anions. J. Scient. Agric. Soc. Finl. 50: 270-275.

JOKINEN, R. 1983. The variability of topsoil properties at the southern coast of Finland and the number of soil samples needed for the estimation of soil properties. J. Scient. Agric. Soc. Finl. 55: 109-117.

KAILA, A. 1971. Effective cation-exchange capacity in Finnish mineral soils. J. Scient. Agric. Soc. Finl. 43: 178-186.

- 1972. Basic exchangeable cations in Finnish mineral soils. J. Scient. Agric. Soc. Finl. 44: 164-170.

- 1973. Calcium, potassium and magnesium in mineral soils from southern half of Finland. J. Scient. Agric. Soc. Finl. 45: 254-261,

KerÄNEN, T. 1966. Karjanlannan kasvinravinteet. Zusammenfassung: Pflanzennăhrstoffe im Stallmist. Maatalous ja Koetoiminta 20: 7-13.

KÄHÄRI, J. 1974. Lietelannan kasvinravinnepitoisuuksista. Abstract: Plant nutrient content in liquid manure. J. Scient. Agric. Soc. Finl. 46: 215-219.

— \& Elonen, P. 1969. Effect of placement of fertilizer and sprinkler irrigation on the development of spring cereals on the basis of root investigation. J. Scient. Agric. Soc. Finl. 41: 89-104.

LaKanen, E. \& Hyvárinen, S. 1971. The effect of some soil characteristics on the extractability of macronutrients. Ann. Agric. Fenn. 10: 135-143.

Lewis, T.E. \& Broadbent, F.E. 1961. Soil organic matter-metal complexes: IV. Nature and properties of exchange sites Soil Sci. 91: 393-399.

MartTILA, U. 1965. Exchangeable cations in Finnish soils. J. Scient. Agric. Soc. Finl. 37: 148-161.

Ross, G.J., Lawton, K. \& Ellis, B.G. 1964. Lime requirement related to physical and chemical properties of nine Michigan soils. Soil. Sci. Soc. Amer. Proc. 28: 209-212.

SAlONEN, M. 1949. Tutkimuksia viljelykasvien juurten sijainnista. Summary: Investigations on the root positions of field crops in the soils of Finland. Acta Agric. Fenn. 70, 1: 1-94.

- 1951. Muokkauskerroksen alla olevien maakerrosten merkityksestä kasvinviljelyssä. Summary: On the significance of subsoil to crop plants. J. Scient. Agric. Soc. Finl. 23: 33-43.

-, Koskela, I. \& KĂhĂrı, J. 1973. The dependence of phosphorus uptake of plants on the properties of the soil. Ann. Agric. Fenn. 12: 161-171.

Steel, R.G.D. \& Torrie, J.H. 1960. Principles and procedures of statistics. 481 p. New York.

StÁlberg, S. 1984. Rapid acid and base titration of soil for determination of exchangeable cations and CEC. Acta Agric. Scand. 34: 71-83.

Urvas, L., Erviö, R. \& Hyvărinen, S. 1978. Soil nutrient status as related to soil textural classification. Ann. Agric. Fenn. 17: 75-82.

WIKLANDER, L. 1970. Utlakning av näringsämnen I. Halter i dräneringsvatten. Summary: Leaching of plant nutrients I. The contents in drainage water. Grundförbăttring 23: 117-141.

Ms received September 14, 1984 


\section{SELOSTUS}

\section{Muokkauskerroksen ja pohjamaan ominaisuudet eteläisen Suomen rannikkoalueen viljelyksillä}

\section{Raili Jokinen}

Helsingin yliopisto, maanviljelyskemian laitos

Tutkimuksen aineisto koottiin Viikin opetus- ja koetilan pelloilta 382 pisteestă, joista jokaisesta otettiin muokkauskerrosta $(0-25 \mathrm{~cm})$ ja pohjamaata $(30-50$ $\mathrm{cm}$ ) edustava năytepari. Kaikista năytteistă mäăritettiin raekoostumus $\%$, orgaaninen $\mathrm{C} \%, \mathrm{pH}\left(\mathrm{CaCl}_{2}\right)$, vaihtuvat ( $\mathrm{pH} 7$ ) kationit $\mathrm{Ca}, \mathrm{Mg}$ ja $\mathrm{K} \mathrm{mg} / \mathrm{kg}$, efektiivinen kationinvaihtokapasiteetti $\mathrm{me} / \mathrm{kg}$, vaihtuva happamuus $(\mathrm{Al}+\mathrm{H}) \mathrm{me} / \mathrm{kg}$ ja kasveille käyttökelpoinen (Bray 1) $\mathrm{P} \mathrm{mg} / \mathrm{kg}$ maata. Muokkauskerroksen ja pohjamaan ominaisuuksia verrattiin toisiinsa koko aineistossa sekä lisăksi kahdella eri perusteella luokitelluissa aineiston osissa. Kalkeissa, lannoitteissa ja karjanlannassa kymmenenă vuotena ennen nåytteiden ottoa annetut $\mathrm{P}, \mathrm{K}$ ja $\mathrm{Mg}$ mäărăt arvioitiin Viikin opetus- ja koetilalla tehtyjen muistiinpanojen mukaan. Karjanlannan ja lietelannan ravinnepitoisuuksista käytettiin KERĀSEN (1966) ja KÁHÄRIN (1974) esittämiä keskimääräisiä arvoja.

Muokkauskerroksessa karkeat kivennăismaat olivat yleisempiä kuin pohjamaassa (Taulukko 2). Aitosavi puuttui lähes kokonaan muokkauskerroksen năytteistä. Keskimăäräinen orgaanisen $\mathrm{C}$ pitoisuus ja $\mathrm{pH}\left(\mathrm{CaCl}_{2}\right)$ olivat pohjamaassa alhaisemmat, saves- ja hiesupitoisuus taas korkeammat kuin muokkauskerroksessa.

Vaihtuvan kalsiumin ja kaliumin sekä kasveille käyttökelpoisen fosforin keskimäăräinen pitoisuus oli muokkauskerroksessa korkeampi kuin pohjamaassa (Taulukko 3), osittain kalkituksen ja lannoituksen seurauksena. Kalsiumpitoisuuksien ero oli sama niilläkin lohkoilla, joita ei oltu kalkittu. Vaihtuvan magnesiumin pitoisuus sen sijaan oli pohjamaassa korkeampi kuin muokkauskerroksessa, ja Litorinamaat poikkesivat muista pohjamaan erittäin alhaisen magnesiumpitoisuuden vuoksi (Taulukko 5). ( $\mathrm{Al}+\mathrm{H})$ osuus efektiivisestä kationinvaihtokapasiteetista $(\mathrm{Ca}+\mathrm{Mg}+\mathrm{Al}+\mathrm{H})$ oli Litorinamaiden pohjamaissa oli $50 \%$ ja ero vastaavaan muokkauskerrokseen ( $9 \%$ ) sekă ei-Litorinamaihin (muokkauskerros $5 \%$, pohjamaa $13 \%$ ) oli huomattavan suuri. Pohjamaiden eri ominaisuuksien vaihtelu oli laaja, mikă viittaa tămăn kerroksen muokkauskerrosta suurempaan epätasaisuuteen.

Pohjamaissa vaihtuvan $\mathrm{Ca}$ tai $\mathrm{K}$ pitoisuuden positiivinen riippuvuus savespitoisuudesta oli kiinteämpi kuin muokkauskerroksessa, vaihtuvan $\mathrm{Mg}$ riippuvuus oli lähes sama kummassakin kerroksessa (Taulukko 6). Savespitoisuuden perusteella ei siis voida arvioida muokkauskerroksen vaihtuvien kationien pitoisuutta kovin suurella varmuudella. Lannoitus ja kalkitus heikentăvăt maassa luontaisesti vallitsevia riippuvuuksia. Litorinamaiden vaihtuvien kationien mäărăn arvioiminen savespitoisuuden perusteella on muokkauskerroksessakin epăvarmaa.

Muokkauskerroksessa vallitsi positiivinen vuorosuhde orgaanisen $\mathrm{C}$ ja vaihtuvan kalsiumin pitoisuuksien vălillä $\left(r=0.38^{* *}\right)$. Pohjamaassa vastaava vuorosuhde oli lähes olematon. Tämă viittaa siihen, ettă orgaaninen aines vähentäă kalsiumin liikkuvuutta maaprofiilissa alaspäin. Vaihtuvan magnesiumin ja kaliumin suhteen ei todettu vastaavaa. 